\title{
Investigation into the Effectiveness of Selected Bio-Based Preservatives on Control of Termite and Fungi of Wood in Service
}

\author{
Faruwa Francis Akinyele, Egbuche C.T., Umeojiakor A. O., Ulocha O. B. \\ Department of Forestry and Wildlife Technology, Federal University of Technology, Owerri, Imo State, Nigeria
}

Email address:

faruwa@gmail.com (F. F. Akinyele)

To cite this article:

Faruwa Francis Akinyele, Egbuche C.T., Umeojiakor A. O., Ulocha O. B.. Investigation into the Effectiveness of Selected Bio-Based Preservatives on Control of Termite and Fungi of Wood in Service. Agriculture, Forestry and Fisheries. Special Issue: Environment and Applied Science Management in a Changing Global Climate. Vol. 4, No. 3-1, 2015, pp. 59-63. doi: 10.11648/j.aff.s.2015040301.20

\begin{abstract}
The study focused on the effectiveness of using bio based preservatives as a controlling measure to biodetoriation from fungi and termite for wood in service. Wood samples of Triplochiton scleroxylon, Gmelina arborea, Ceiba pentandra used for the study were obtained from the sawmill of Ondo State Afforestation Project (OSAP) Oluwa and processed at the wood workshop of the Department of Forestry and Wood Technology, Federal University of Technology Akure. The sample were converted into $60 \mathrm{~mm} \times 20 \mathrm{~mm} \times 20 \mathrm{~mm}$ and seasoned to $12 \%$ moisture content. The samples were treated with biopreservatives from Parkia biglobosa, Tridax procumbens and tar oil obtained via pyrolysis. This study showed that even though Ceiba pentandra has the highest retention for the preservatives, it is the most susceptible to fungal and termite attack. Gmelina arborea with the lowest retention have resistance to termite and fungal attack, thus, the effectiveness of the preservatives on the wood samples is not only determined by the retention level of each preservative but also the chemical constituent $(\mathrm{pH})$ of the preservative. This study recommends the use of tar oil for preservation of the wood samples against termite where colour is not important while, ethanolic extract of Tridax procumbens can be used to preserve wood against fungal attack.
\end{abstract}

Keywords: Ethanolic Extract, Tridax procumbens, Tar Oil, Preservation, Termite

\section{Introduction}

Wood has been a pre-dominantly constructional material for both domestic and industrial use globally. According to [5], more than $80 \%$ of timber product in Nigeria is utilized for construction purposes such as doors, windows, rafters, flooring, panels, purlines, furniture and cabinets making, tool handles, packaging, crates, and bridge carving among others. Despite the usefulness of wood, its service life can be degraded by various biodeteriorating agents; these include fungal infection, termites, insects, marine borers, fire attack and mechanical failure [1]. For effective utilization, wood needed to be protected from the attack on it by decay fungi, harmful insects, or marine borers by applying preservatives.

Wood preservation is the chemical way of conditioning wood to increase its resistance to invading destructive organisms (fungi, insects, marine borers and animals) and deterioration caused by unfavorable environmental conditions to protect the life span of wood in service [4].
The degree of protection achieved depends on the preservative used and the proper penetration and retention of the chemicals. Some preservatives are more effective than others, and some are more adaptable to certain use requirements.

With the current problem of global warming and environmental degradation, Some of the substances used as chemical preservatives have been prohibited due to environmental restrictions and thus, there is a search for alternative techniques which can extend wood service life, and which also at the same time is less harmful to the environment and man [2]. This necessitated the use of natural plant extract (Bio-preservatives) which are less harmful to the environment and more economical to protect wood against degrading agents such as fungi and insect. Biopreservatives constitute a wide range of natural products from both plants and animals which can be useful in the extending shelf life of wood reducing or eliminating survival of pathogenic bacteria and increasing overall quality of the 
wood products. The objective of this study is therefore, to evaluate the effects of plant extracts as preservative on wood and to evaluate their anti-fungal and anti- termite efficacy.

\section{Materials and Methods}

Wood samples of Triplochiton scleroxylon, Gmelina arborea and Ceiba pentandra used for the study were obtained from the wood sawmill of Ondo State Afforestation Project (OSAP) Oluwa and processed at the wood workshop of the Department of Forestry and Wood Technology, Federal University of Technology Akure. The wood samples were dimensioned into $60 \mathrm{~mm} \times 20 \mathrm{~mm} \times 20 \mathrm{~mm}$ and seasoned to $12 \%$ moisture content. The wood samples were treated with bio-preservatives from extracted from Parkia biglobosa, Tridax procumbens and tar oil obtain via pyrolysis. The wood samples were divided into three sets based on the type of Field test to be conducted (Termite and Fungi attack test). A total number of 72 wood samples were used for the test $(3$ from each species treated with bio-preservatives and 3 each as replicate for each species) for each field test (36 each for both Fungi and termite attack). Preparation and impregnation of wood samples were carried out according to ASTMD1413-76 standard. The test samples were marked using a water proof permanent marker for ease identification. Samples were oven dried at $103 \pm 2^{\circ} \mathrm{C}$ for 24 hours and the oven dry weight recorded as $\mathrm{T}_{1}$. Treatment of samples was done using bio preservatives. The method of preservative adopted was cold soaking for 72 hours. The samples were drained of excess preservatives, re-weighed and the treated weight was recorded as $\mathrm{T}_{2}$. Percentage absorption and retention of treated samples was calculated as follow

$$
\begin{aligned}
& \text { Absorption }=100 .\left(\frac{T_{2}-T_{1}}{T_{1}}\right) \\
& \text { Retention }\left(\mathrm{Kg} / \mathrm{m}^{3}\right)=\frac{\mathrm{GC}}{\mathrm{V}} \times 10
\end{aligned}
$$

Where:

$\mathrm{G}=\left(\mathrm{T}_{2}-\mathrm{T}_{1}\right)=$ initial weight of the wood before treatment subtracted from

Initial weight of wood plus treatment,

$\mathrm{C}=$ grams of preservative in $100 \mathrm{~g}$ of treating solution,

$\mathrm{V}=$ volume of sample in $\mathrm{cm}^{3}$

\subsection{Method of Preservative Extraction Tridax procumbens}

Tridax procumbens was collected from the field and air dried at room temperature for 10 days, and pulverized. The ethanolic extract of the sample was prepared by soaking $100 \mathrm{~g}$ of the powdered sample in 1 litre of $95 \%$ ethanol for $24 \mathrm{hrs}$.

\subsection{Parkia Biglobosa}

The seeds of Parkia biglobosa were collected from "Ojaoba" market in Ibadan, and soaked in water for about 15 minutes and washed in water to remove dirt. The seeds were dried and then cooked for 24 hours; the extract was separated from the seeds. Tar oil was obtained from wood pyrolysis at $650^{\circ} \mathrm{C}$ from afzelia africana (apa).

\section{Result and Discussion}

\subsection{Retention}

Table 1 shows the percentage retention of the Biopreservatives on the selected wood species. The result shows that for tar oil treatment, Ceiba pentandra has the highest retention value $(385.41 \pm 35.23)$, followed by Triplochiton scleroxylon $(228.47 \pm 0.03)$ and Gmelina arborea (156.25 \pm 63.10$)$. For P. biglobosa and T. procumbens extracts Triplochiton scleroxylon has the highest retention values. The experiment showed that among all the preservatives used, tar oil is the most retained bio-preservatives.

Table 1. The (Percentage) retention of tar oil, Parkia biglobosa, and Tridax procumbens ethanolic extracts on selected wood species.

\begin{tabular}{llll}
\hline Treatment & Gmelina arborea & Ceiba pentandra & $\begin{array}{l}\text { Triplochiton } \\
\text { scleroxylon }\end{array}$ \\
\hline $\begin{array}{l}\text { Tar oil } \\
\text { Parkia } \\
\text { biglobosa } \\
\text { extract } \\
\begin{array}{l}\text { Tridax } \\
\text { procumbens } \\
\text { extract }\end{array}\end{array}$ & $156.25 \pm 63.10^{\mathrm{a}}$ & $385.41 \pm 35.23^{\mathrm{a}}$ & $228.47 \pm 0.03^{\mathrm{a}}$ \\
\hline
\end{tabular}

Value are mean $\pm \mathrm{SE}$. Value with same superscript are not significantly different $(*)$, but different superscript means they are significantly different (ns) at $\mathrm{p} \leq 0.05$.

\subsection{Absorption}

Table 2 shows the percentage absorption of the preservatives on wood. Ceiba pentandra has the highest absorption (113.61 \pm 8.02$)$, followed by Triplochiton scleroxylon $(55.25 \pm 10.14)$ and Gmelina arborea

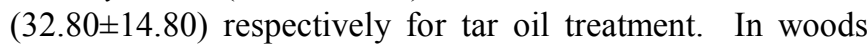
treated with Parkia biglobosa extract, Gmelina arborea and Triplochiton scleroxylon had the lowest (54.33) and highest(128.98) absorption respectively, while for wood treated with Tridax procumbens extract. Ceiba pentandra had the highest absorption (77.23 \pm 44.10$)$, while Gmelina arborea and Triplochiton scleroxylon had lower absorption, with the value of the two wood species having no significant differences $(\mathrm{P}>0.05)$.

Table 2. (\%) absorption of tar oil, Parkia biglobosa, and Tridax extracts on selected wood species

\begin{tabular}{llll}
\hline $\begin{array}{l}\text { Treatment/ } \\
\text { species }\end{array}$ & Gmelina arborea & Ceiba pentandra & $\begin{array}{l}\text { Triplochiton } \\
\text { scleroxylon }\end{array}$ \\
\hline $\begin{array}{l}\text { Tar oil } \\
\text { Parkia } \\
\text { biglobosa } \\
\text { extract }\end{array}$ & $32.80 \pm 14.80^{\mathrm{c}}$ & $113.61 \pm 8.02^{\mathrm{a}}$ & $55.25 \pm 10.14^{\mathrm{b}}$ \\
$\begin{array}{l}\text { Tridax } \\
\text { procumbens } \\
\text { extract }\end{array}$ & $22.56 \pm 8.06^{\mathrm{b}}$ & $77.23 \pm 44.10^{\mathrm{a}}$ & $12.55 \pm 16.69^{\mathrm{c}}$ \\
\hline
\end{tabular}

Value are mean $\pm \mathrm{SE}$. Value with same superscript are not significantly different $(*)$, but different superscript means they are significantly different (ns) at $\mathrm{p} \leq 0.05$. 


\subsection{Weight Loss}

\subsubsection{Percentage Weight Loss as a Result of Termite Infestation}

Table 3 shows the result for the percentage weight loss that occurred in the wood species after 12 weeks of exposure to termite attack. The Table showed that Gmelina arborea has the lowest weight loss, followed by Triplochiton scleroxylon, with Ceiba pentandra having the highest weight loss for the treated samples, while the untreated wood species has the highest overall weight loss. There is no significant difference within wood treated with tar oil, but for the other treatment, there is significant difference among the wood species. This means that Gmelina arborea treated with tar oil had the highest resistance to termite attack (18.40 44.57$)$.

Table 3. \% weight loss of wood after exposure to termites attack

\begin{tabular}{llll}
\hline \multirow{2}{*}{ Preservatives } & \multicolumn{3}{l}{ Weight loss of selected wood species } \\
\cline { 2 - 4 } & $\begin{array}{l}\text { Gmelina } \\
\text { arborea }\end{array}$ & $\begin{array}{l}\text { Ceiba } \\
\text { pentandra }\end{array}$ & $\begin{array}{l}\text { Triplochiton } \\
\text { scleroxylon }\end{array}$ \\
\hline $\begin{array}{l}\text { Taroil } \\
\text { Parkia Biglobosa } \\
\text { extract }\end{array}$ & $18.40 \pm 4.57$ & $46.37 \pm 26.01$ & $26.22 \pm 8.67$ \\
$\begin{array}{l}\text { Tridax procumbens } \\
\text { extract }\end{array}$ & $10.50 \pm 6.63$ & $100.00 \pm 0.00$ & $47.01 \pm 46.01$ \\
Control & $20.13 \pm 14.92$ & $100.00 \pm 0.00$ & $100.00 \pm 0.00$ \\
\hline
\end{tabular}

Value are mean $\pm \mathrm{SE}$. Value with same superscript are not significantly different $(*)$, but different superscript means they are significantly different (ns) at $\mathrm{p} \leq 0.05$.

\subsubsection{Percentage Weight Loss as a Result of Fungi Infestation}

Table 4 shows that Gmelina arborea treated with Tridax procumbens extract has the lowest weight loss (8.26 18.86$)$, but there is no significant difference in treatment effect of wood species treated Tridax procumbens extract. Ceiba pentandra treated with Parkia Biglobosa extract have the highest weight loss (61.29 \pm 6.66$)$.Generally, there is significant difference among treatment.

Table 4. \% weight loss of wood after inoculation of fungi

\begin{tabular}{llll}
\hline \multirow{2}{*}{ Preservatives } & \multicolumn{3}{l}{ Weight loss of selected wood species } \\
\cline { 2 - 4 } & $\begin{array}{l}\text { Gmelina } \\
\text { arborea }\end{array}$ & $\begin{array}{l}\text { Ceiba } \\
\text { pentandra }\end{array}$ & $\begin{array}{l}\text { Triplochiton } \\
\text { scleroxylon } \\
\text { Taroil } \\
\begin{array}{l}\text { Parkia Biglobosa } \\
\text { extract }\end{array}\end{array}$ \\
$\begin{array}{l}\text { Tridax procumbens } \\
\text { extract }\end{array}$ & $14.73 \pm 0.56$ & $39.28 \pm 9.22$ & $27.83 \pm 14.00$ \\
Control & $8.26 \pm 8.86$ & $9.63 \pm 3.59$ & $11.16 \pm 7.72$ \\
\hline
\end{tabular}

\subsection{Result for Visual Observation}

\section{Visual Observation After Exposure to Termite}

This study revealed that wood species treated with tar oil had the highest rating, meaning that it is resistance to termite attack. Figure 1 showed that Ceiba pentandra treated with Tridax procumbens extracts was attacked by termite within two weeks of field test. After four weeks of exposure to termite Ceiba pentandra treated with Tridax procumbens extract have been completely deteriorated and at ten weeks Ceiba pentandra and Triplochiton scleroxylon treated with Tridax procumbens and Parkia biglobosa had failed. At the end of twelve weeks of observation untreated Ceiba pentandra and Triplochiton scleroxylon, also Ceiba pentandra treated with Tridax procumbens and Parkia biglobosa have been completely deteriorated by termite. This shows that Ceiba pentandra is the most susceptible to termite attack.

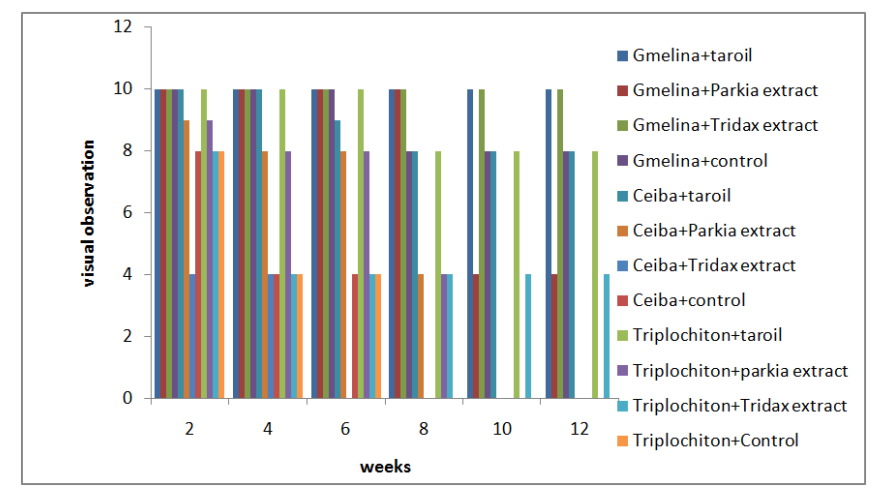

Figure 1. visual observation of wood species exposed to termite deterioration

Visual observation after inoculation of fungi Figure 2 showed that there is no growth of mycelium on wood species treated with tar oil, wood treated with Parkia biglobosa reveal growth of mycelium.

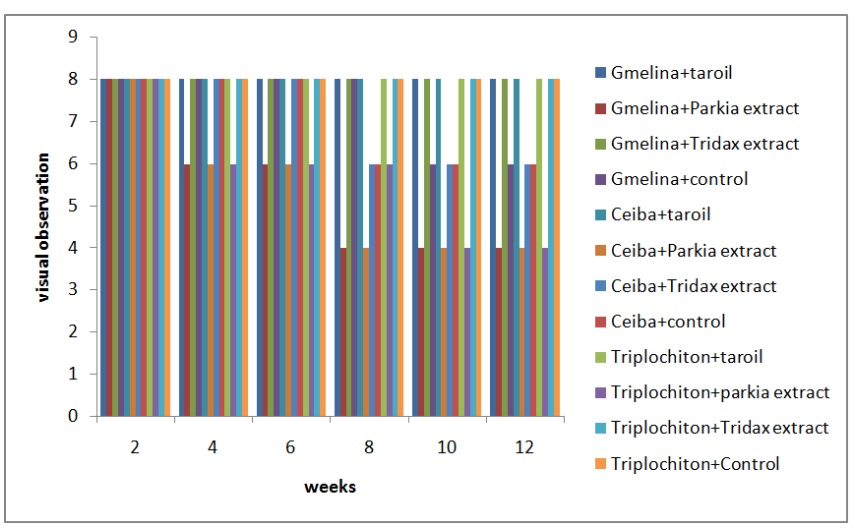

Figure 2. Visual observation after inoculation of fungi on wood species

\section{Discussion}

\subsection{Retention}

The result in Table 1 showed that the retention of preservatives on the wood species is significantly different. This agrees with the result obtained by [7] that wood exhibit variation in absorption and retention of chemical preservatives when treated with wood species. This variation in biocide retention may occur due to variation in the anatomical structure of wood species. Also, this view is supported by [5] where he reported that the amount of 
preservative retained in the cellulose material possibly varies due to differences in anatomical structures of the various wood species. However, for the preservative treatment, tar oil is highly retained by the three wood species selected when compared with retention of other preservatives. This may be due to its oil based attribute and its viscosity.

\subsection{Absorption}

As shown in Table 3, Triplochiton scleroxylon has the highest absorption. This correlates with the work of [3] where he reported that anatomical structure of wood exhibit a lot of influence on the absorption and retention of wood preservatives. The differences in absorption could be as a result of extractives deposited in the wood samples.

\subsection{Weight Loss After Exposure to Termite Attack}

The result revealed that wood treated with tar oil had the lowest weight loss. This shows that tar oil is effective for preservation of wood against termite attack but Tridax procumbens and Parkia biglobosa had the highest weight loss, this indicate that these two treatment are not effective against termite attack. The effectiveness of tar oil may be because is highly toxic as it is found to contain carboxylic acid in greater percentage as reported by [8]

\subsection{Weight Loss After Inoculation of Fungi}

This study showed that untreated wood samples and wood samples treated with Parkia biglobosa extracts have means with the lowest weight loss, while wood species treated with Tridax procumbens extract have the highest mean for weight loss, followed by wood species treated with tar oil. From this study Ceiba pentandra have the highest weight loss, followed by Triplochiton scleroxylon, and Gmelina arborea have the lowest weight loss, this may be due to variation in the anatomical structure and the natural durability of wood.

Visual observation for termite deterioration. This indicates that Parkia biglobosa and Tridax procumbens extracts are not effective for the preservation of wood against termite attack. Tar oil is the most effective preservative of the selected preservatives on the wood species but the limitation is that it impacts colour on the wood, this is in conformity with the work of [1] that pyrolytic oil and Jatropha oil are effective for the preservation of wood. Tar oil can be recommended for the protection of the selected wood species against termite attack.

\subsection{Visual Observation for Fungi Deterioration}

This study shows that wood samples treated with Tridax procumbens extract does not show the growth of fungi mycelium, this indicate that the extract is capable of protecting wood samples against fungal attack, this is in agreement with the findings of [6], while working on the antifungal property of Tridax procumbens L. against three phytopathogenic fungi. This is supported by similar work carried out by [9], he reported the antifungal activities of crude medicinal plant species including Ocimum sanctum, Ricinus communis and Jatropha curcas. Wood samples treated with parkia biglobosa revealed growth of fungal mycelium. It was observed that Ceiba pentandra is more susceptible to fungi deterioration and this might be due to the differences in the physical properties of the two wood samples.

\section{Conclusion}

This study showed that even though Ceiba pentandra has the highest retention for the preservatives, it is the most susceptible to fungal and termite attack. But Gmelina arborea with the lowest retention have resistance to termite and fungal attack, so the effectiveness of the preservatives on the wood samples is not only determined by the retention level of each preservative but also the chemical constituent of the preservatives.

In conclusion, after twelve weeks of field test, for the termite deterioration tar oil is found to be the most effective preservative, and for the fungal deterioration Tridax procumbens extract was found to be the most effective.

This study recommends the use of tar oil for preservation of the wood samples against termite where colour is not important, and Tridax procumbens from ethanolic extract can be use to preserve wood against fungal attack.

\section{References}

[1] Areo O. O (2002): Preservation of small round logs of Tectona grandis exposed to termite attacks using copper chromium arsenate (CCA). An HND submitted to the Federal College of Forestry, Ibadan.

[2] Arldo C.Bernardis and Orlando popoff (2009): Durability of pinus elliottii wood impregnated with quebracho Colorado (schinopsis balansae) bio-protectives extracts and CCA. Maderas Ciencia technologia 11(2):106-115.

[3] Desch, J.M. (1981): Timber Its nature and behaviour, van Nostrand Reinhold Co. Ltd, Bershire, England. 170pg.

[4] Elegbede M.O (2002): A profile of wood preservation industry in Ibadan and Lagos Metropolis. A project submitted to Department of Wood and Paper Technology in the Federal College of Forestry, Ibadan Oyo state pg 2-4

[5] Ogbogu G.U (1996): The State of Wood Treatment Technology in Nigeria Institute of Nigeria

[6] Sandeep Acharya and Srivastava R.C.(2010): Antifungal property of Tridax procumbens $L$. against three pythopathogenic fungi Arch. Arch. Pharm. Sci. \& Res Vol. 2, No.1, pg 258-263.

[7] Schutlz, T.P, Nicholas, D.D, Henry, W.P, Pittman, C.U, Wipf, D.O and Goodell, B. (2005): Review of laboratory and out door exposure efficacy results of organic biocide; antioxidant combinations, an initial economic analysis and discussion of a proposed mechanism. Wood and Fiber Science. 37(1); (175184).

[8] Sipilae` K, Kuoppala E, Fagernae`s L (1998). Characterization of biomass-based flash pyrolysis oils. Biomass Bioenergy ; 14(2): 103-13 
[9] Siva, N., Ganesan, S., Banumathy, N. and Muthuchelian (2008): Antifungal Effect of Leaf of Extract of Some Medicinal Plants Against Fusarium oxysporum Causing Wilt Disease of Solanum melongena L. Ethnobotincal Leaflets 12: 156-163. 